\title{
The Limbu Script and the Production of Religious Books in Nepal
}

\author{
Martin Gaenszle | ORCID: 0000-0002-0782-1413 \\ Institut für Südasien-, Tibet- und Buddhismuskunde, Universität Wien, \\ Vienna, Austria \\ martin.gaenszle@univie.ac.at
}

\begin{abstract}
With the rise of ethnic politics in Nepal, the Limbu (or:Yakthumba) have made increasing use of the Limbu script, also known as Srijanga or Kiranti. Whereas in the past this script was suppressed by the state and known only to a minority, since the return of democracy to Nepal in the 199os a new literature using this script has come into being. Here, religious books play a prominent role. This essay deals with the emerging importance of the script as a marker of ethnicity since its first general propagation by Iman Singh Chemjong and Phalgunanda Lingden in the early twentieth century. It focuses on the early production of printed books, in particular books published by followers of the Satyahangma movement, which promotes reforms of Kiranti religion and society.
\end{abstract}

\section{Keywords}

oral tradition - writing systems - invention of scripts - print history - religious reform - Nepal

But the specific pre-eminence of the written word over images is stoutly maintained. As one Tibetan scholar stated it, "One letter formed is of greater value than a likeness of Buddha formed, for the letter aids knowledge." This statement, and the attitudes and behavior pattern of which it is the expression, suggests that, among the Tibetans, grapholatry is more real than idolatry.

ROBE RT E KVALL, Religious Observances in Tibet (1964), 114. 
In recent years, in the context of ethnic politics in Nepal, the Limbu script has received increasing value in the process of the creation of Limbu traditions. This gives the impression that grapholatry is of similar importance in eastern Nepal to that ascribed by Ekvall to Tibet. Formerly, and in most rural places still today, the religious practice of the Limbu (Yakthumba) of Nepal was entirely an oral tradition in their native language, a language belonging to the Kiranti family of Tibeto-Burman. This is likewise true for all the other ethnic groups that identify as Kiranti or Kirat, such as the more than two dozen Rai groups, the Yakkha, and the Sunuwar. This oral tradition, known as Mundhum among the Limbu (and by various cognate terms among the other groups), ${ }^{1}$ was originally performed without any written form of the text by shamans and priests during often long recitations and ritual activities. Practitioners received knowledge of these texts in dreams and were supported by senior ritual experts. Even if written forms existed, reading these texts was generally seen as utterly improper.

The situation has changed dramatically in the last three decades. With the rise of ethnic politics, the Limbu have begun to stress the distinctiveness of their religion, in the past regarded as "Hindu" by outsiders and census officials. ${ }^{2}$ In the process of various reforms and revisions, they made increasing use of the Srijanga script, which was invented in the eighteenth century. After undergoing several modifications, today it is generally known as Limbu or Kiranti script (on the question of its various names, see below). Whereas in the past this script was suppressed by the Nepali state and had no wider cultural importance, the situation changed fundamentally upon the return of democracy to Nepal in the 1990s. Since then, a new literature has come into being. Initially it involved mainly religious books.

1 Variant terms are Muddum (Mewahang Rai), Mindum (Yamphu Rai), Muntum (Yakkha) or Ridum (Kulung Rai); see Martin Gaenszle, Ancestral Voices: Oral Ritual Texts and their Social Contexts among the Mewahang Rai in East Nepal (Münster, Hamburg, London: LIT Verlag, 2002), 41 .

2 On the Limbus' changing context of community making, see Mélanie Vandenhelsken and Martin Gaenszle, "Limbu Religion and the Remaking of the Community," in Brill's Encyclopedia of Religions of Indigenous People of South Asia, ed. Marine Carrin and Gérard Toffin (Leiden: Brill, 2019), http://dx.doi.org/10.1163/2665-9093_BERO_COM_O32248, accessed April 17, 2021. The category of "Kirat" as a religious designation was already introduced in the census of 1991. According to the census of 2011, 3,1 \% of Nepal's population considers itself as following this religion; see свs (Central Bureau of Statistics), National Population and Housing Census 2011 (Kathmandu: Government of Nepal [National Planning Commission Secretariat], 2012), 4 . 
This article deals with the early history of the production in Nepal of religious books printed in Limbu script. This process largely coincides with a process of "literization" (using the terminology suggested by Sheldon Pollock), ${ }^{3}$ that is, the writing down of oral texts in a script (German Verschriftlichung). But here the process has also been accompanied by what Pollock calls "literarization": the creation of a literary tradition involving the establishment of a canon and the emergence of a specific linguistic style. As I will try to show, this linguistic style, including editorial conventions, has been intimately linked to the production of religious (Mundhum) texts in this unique ethnic script. This has endowed the script with a particular sanctity. The new tradition of using this script, with its distinct graphic form, is valued as a powerful cultural marker of indigeneity, and thus the script itself has become highly esteemed, indeed has become as much an object of veneration as the content of the texts it is used for.

Similar developments elsewhere in South Asia have been described, confirming the common observation that the use of a distinct script disseminated by print publications is a powerful resource in ethnic or nationalist movements. Such scripts epitomize claims for cultural autonomy. The term "print communalism" has been suggested by Udupa in response to Anderson's notion of "print capitalism"; 4 analogously one might speak of "script communalism." However, given the specific associations of the term "communalism" in India, I prefer to speak of "script community." A case in point is the Ol-Chiki script of the Santal, which was invented and introduced by a school teacher during India's colonial period. ${ }^{5}$ In India, the contemporary ethnopolitical context of "reservation" entails a state-defined ideal of "tribalism," with Scheduled Tribes

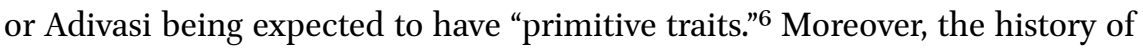
such "tribal" communities is often affected by Christian missionary activities.

3 Sheldon Pollock, "India in the Vernacular Millennium: Literary Culture and Polity, 10oo1500," Daedalus 127, no. 3 (1998): 41. Also see Sheldon Pollock, The Language of the Gods in the World of Men: Sanskrit, Culture, and Power in Premodern India (Berkeley: University of California Press, 2006), 4-5.

4 Sahana Udupa, "Print Communalism: The Press and the Non-Brahmin Movement in Early Mysore, 1900-1930," Contributions to Indian Sociology 44, no. 3 (2010): 265-297; Benedict Anderson, Imagined Communities: Reflections on the Origins and Spread of Nationalism (London: Verso, 1991).

5 Nishaant Choksi, "From Language to Script: Graphic Practice and the Politics of Authority in Santali-language Print Media, Eastern India," Modern Asian Studies 51, no. 5 (2017):1519-156o.

6 Sara Shneiderman and Mark Turin, "Seeking the Tribe: Ethno-politics in Darjeeling and Sikkim," Himal Southasian 19, no. 2 (2006): 54-58; see also Sara Shneiderman, Rituals of Ethnicity: Thangmi Identities between Nepal and India (Philadelphia: University of Pennsylvania Press, 2015), 157 . 
In contrast, the case of the Limbu in Nepal seems more strongly marked by internal forces of revitalization.

To begin, I will give a short introduction to the history of the Limbu script, then will give a brief outline of the beginnings of Limbu book production, and finally will focus on the role of the reformist Satyahangma movement in the popularization of the script. It was in particular this movement for a new religion, I argue, that insisted on the exclusive right to use this indigenous script in its struggle for religious, social and political change. But as will be shown, alongside the publication of ritual texts for religious use, more scholarly types of books with a distinct style of presentation were also produced. Since the 1990s, the printing of multi-script books has become more common. ${ }^{7}$

\section{The Invention of the Limbu Script}

The history of the Limbu script can be traced back to the eighteenth century, when Srijanga, a Limbu monk said to be affiliated with a monastery in Sikkim, began to propagate a Kiranti script. ${ }^{8}$ In the local view, Srijanga is credited with the re-discovery of an ancient script, which, so the story goes, had been in use in the second half of the first millennium, was "lost" for some eight hundred years, and then found again. ${ }^{9}$ However, in historical documents there is no indication that this script had any predecessors. Rather the available sources suggest that the script was an invention introduced by Srijanga in an act of resistance. Manuscripts in the Hodgson Collection in the British Library ${ }^{10}$ contain information about these events and indicate that Srijanga, apparently also known as Rupihang, was viewed as a separatist by the king of Sikkim.11 The script is a variant of South Asian abugida (alphasyllabary) scripts and is

7 On the earlier difficulties of producing such books in South Asia, see Francesca Orsini, ed., The History of the Book in South Asia (Farnham \& Burlington: Ashgate, 2013), xviii.

More detailed accounts of this process are given in Martin Gaenszle, "Scripturalisation of Ritual in Eastern Nepal," in Ritual, Heritage and Identity: The Politics of Culture and Performance in a Globalised World, ed. Christiane Brosius and Karin M. Polit (New Delhi: Routledge, 2011), 281-297, and Martin Gaenszle, "The Power of Script: Phalgunanda's Role in the Formation of Kiranti Ethnicity," in Routeing Democracy in the Himalayas: Experiments and Experiences, ed. Vibha Arora and N. Jayaram (New Delhi: Routledge, 2013), 50-73.

9 Chaitanya Subba, The Culture and Religion of Limbus (Kathmandu: K.B. Subba, 1995), 32.

10 Cf. John Whelpton and Michael Hutt, "The Catalogue of the Hodgson Collection in the British Library," European Bulletin of Himalayan Research 39 (2011): 128-143.

11 Ramesh Dhungel, "The Long-Ago Fight for Kirant Identity," Himal Southasian (October 2006): $5^{2-56 .}$ 
thought to have been inspired by the Lepcha script (which was invented only a few decades earlier). It also resembles in part the Tibetan script. Apparently, the purpose of Srijanga's creation was to give his Limbu brethren a distinct medium to write down their own oral tradition. This, it seems, was seen as threatening and insubordinate by the royalty of Sikkim, who had certain claims of sovereignty over a part of the eastern region of what is now Nepal. Ultimately Srijanga was murdered, most probably on the order of these rulers.

This story shows that possessing a script was not only a religious resource, but also a political issue. Having a script meant having cultural capital intimately linked to power, sovereignty, and independence. For these reasons, it was a highly contested issue. During the Rana autocracy (1846-1951), the use of the Limbu script was strictly outlawed and its use was punished as an act of sedition. This situation was still strongly felt during the Panchayat era (1961-1990), the time of "partyless democracy," when the monarchy in Nepal enforced a cultural nationalism in which the Nepali language written in the Devanagari script was promoted, whereas the use of other scripts was highly restricted. Print publications in minority scripts were largely banned through censorship. ${ }^{2}$

Today in eastern Nepal, as well as in Darjeeling and Sikkim, Srijanga is memorialized and celebrated by the Limbu as a founding ancestor, a kind of cultural hero. He is often depicted in the St. Sebastian posture, pierced by many arrows, and thus has some resemblance to a Christian martyr. At the entrance to the capital of Sunsari District, the town of Dharan, which has a high percentage of well-to-do Kiranti (members of both the Rai and Limbu communities), there is a large statue of Srijanga, his body full of arrows. It is a memorial with a clear message: our forefather and brave hero was killed by alien ruling forces who suppressed our culture.

The script invented by Srijanga continued to be developed further. As far as we know, it was not used much in the nineteenth century, at least not as a means for transmitting a tradition. But in the 1920s there was a real revival, a fresh rediscovery of the script. Above all, it was Iman Singh Chemjong (19041975), a young Limbu reformer and activist, who revised the Srijanga script and added a few letters to make it more compatible with Devanagari reading habits. Chemjong's version was further revised by B.B. Subba in the 196os. It is this

12 The legal situation was somewhat ambivalent: there was no law directly prohibiting the use and distribution of the script. For example, handwritten copies of religious texts were in use locally, and Iman Singh Chemjong published three Limbu primers in the script using cyclostyle copy technology (Bairagi Kainla, personal communication). However, any ethnic publications regarded as politically motivated were banned, and numerous publishers who evaded this ban were put in jail. 
form of the alphabet that is now the standard form. ${ }^{13}$ In the following I will use the designation "Limbu script" only for this version of the alphabet, which is now generally used for printing. ${ }^{4}$

Chemjong was educated at a "mission school" in Calcutta, so there were Christian influences in his schooling. But he was motivated to work for the Kiranti cause by Limbu elites who resided in Darjeeling and were active in a general Limbu cultural revival in the context of the colonial situation. At that time, Darjeeling was a hotspot of ethnic activism, and schools were founded which tried to offer a new kind of education. For example, the Yakthunghang Chumlung Sabha, the first and oldest Limbu ethnic organization, was established in 1925 and began to run a school, the Jambok Memorial School. In this context, the rediscovery of the Kiranti script played an important role. ${ }^{15}$

More important for the development of the movement in Nepal was a religious leader, a Limbu ascetic by the name of Phalgunanda Lingden (18851949). Born in Panchthar District to a poor family, he later became a member of the British army, which he then left because of religious inclinations. Indeed, he had a mission: a vision of the revival of Kiranti culture. He was a soldier in World War I, fighting on the British side, first in Burma and later in Europe. It was then that he had religious experiences in which he saw the futility and craziness of war: one day during a fight, the story goes, he started shooting either into the air or into the ground, because he saw all the other soldiers as his brothers and could not shoot at them. Miraculously, he remained unhurt. He returned to Nepal, and after going on pilgrimages and retreats during the 1920s, he finally "discovered" the Kiranti script in a cave. ${ }^{16}$

Still earlier than that, there had been attempts by Limbu leaders to reform their own culture, apparently because they saw the need to confront the dominating Hindu religion with a new kind of tribal religion, something of their

13 On the history of the script, see George van Driem, A Grammar of Limbu (Berlin, etc.: Mouton de Gruyter, 1987), 550-558. See also R.K. Sprigg, "Limbu Books in the Kiranti Script," in Akten des vierundzwanzigsten internationalen Orientalisten-Kongresses, München, 1957, ed. Herbert Franke (Wiesbaden: Steiner Verlag, 1959), 590-592.

14 It should be added that in today's context of ethnic politics, the name of the script is highly controversial: whereas many of the Rai community prefer the inclusive designation Kiranti or Kirat script (the latter term was also used by Chemjong), many Limbu, in particular in Sikkim, insist that it should be seen as an exclusively Limbu script. I do not side with any of these parties, but follow the terminology now associated with the Unicode character set (see below). However, it should be added that the Limbu ethnic association Kirat Yakthung Chumlung has officially opted for the designation "Kirat Sirijonga script."

15 Subba, The Culture and Religion of the Limbu, 33 .

16 Gaenszle, The Power of Script, $5^{8-59}$. 
own. In 1931, a major meeting was held, the Yakthung Chumlung Satya Dharma Muchulka, at which Limbu leaders decided to change some basic aspects of the tradition. Phalgunanda was an enthusiastic propagator of these new ideas; he asked his Kiranti brothers and sisters to stop drinking alcohol and eating meat and to lead a more truthful and pure kind of lifestyle. This new religion was called the Satya Dharma or Satyahangma (referring to the divinity). After Phalgunanda "discovered" the Kiranti script, he fought not only for using the script, but also for introducing more systematic and widely available education, which at that time under the autocratic rule of the Ranas was something not accessible to the common public. Thus, one can say that Phalgunanda was not only a religious leader, but also a social reformer. Not surprisingly, he was increasingly seen by the Rana elites as a dangerous and seditious element. He was even accused at one point, in 1938, of being an anti-national (räjdrohi) leader, whereupon he had to defend himself at the local court in Dhankuta. He was acquitted due to lack of evidence.

Phalgunanda's strategic use of the Kiranti script was thus part of a general reform of the Limbu religious tradition and society. Nonetheless, the reverence in which the script was held also contained elements of grapholatry, since the major texts published in the script were used in religious rituals. After Phalgunanda's death, the Satyahangma movement dwindled and almost disappeared. However, in the 1970s a successor appeared, Atmananda Lingden, who today continues the work of preaching about the new Kiranti religion and is an important sponsor of printing religious books in the Limbu script (see below).

\section{The Production of Printed Mundhum Books: Historical Context}

Since the ethnic revival of the 199os, for Limbus in Nepal possessing a distinct script has become a highly valued badge of identity. ${ }^{17}$ The Limbu script was already popular in India (Sikkim, Darjeeling) before this time. In Nepal, however, it had long been a victim of censorship and thus could only be used in a restricted manner. Followers of the Satyahangma religion, for example, could recite from handwritten texts, and ethnic intellectuals clandestinely brought back books from India. But with the reestablishment of multiparty democracy, the de facto ban on publications in ethnic scripts was lifted. Interestingly, there

17 Martin Gaenszle, "Redefining Kiranti Religion in Contemporary Nepal," in Religion, Secularism, and Ethnicity in Contemporary Nepal, eds. David N. Gellner et al. (New Delhi: Oxford University Press), 326-352. 
were also some Rai in Nepal who began using their own distinct Rai script in the 1990s, although they had never done so before. ${ }^{18}$ Nonetheless, today many Rai regard the Srijanga-derived scripts as belonging to all Kiranti and see no reason to use a different one.

The importance of the Limbu script materialized only slowly, since printing the script was not easy. Until the early 199os, there was no standardized Limbu font used in Nepal. Most early books available in Nepal were produced in Kalimpong and Sikkim, but these were mainly textbooks (or rather booklets) with alphabets to propagate the use of the script (sāpla in Limbu). ${ }^{19}$ As far as we know, these books, reproduced in small numbers using the cyclostyle copying technique, were distributed only locally.

By the 1950s a few works had been published in the Limbu language (albeit printed in Devanagari), for example works by the Limbu writer Kajiman Khandangwa. These, like works by Bairagi Kainla, were part of the avant-garde in Nepali literature. While Kajiman Khandangwa deliberately drew on his ethnic background and experience, he came to be known mainly for his writing in Nepali. From the mid-196os, a few Limbu-language journals and magazines began to be published, including Kom (edited by Birahi Kainla, a cousin of Bairagi Kainla) and Srijanga. But again, prior to the 199os these were printed in Devanagari script.

\section{Overview: Book Genres, Production Context, Developments}

Publication activities have changed since 1990. Some preliminary observations about this can be made by looking at Limbu ethnic libraries, such as the Yakthung Chumlung library in Patan (Lalitpur District). Any such library in Nepal must be regarded as incomplete, since many books in Limbu are published privately in limited runs (often not more than 5 oo copies) and are

18 A script developed in the late 196os in Sikkim by Kripashalyan Rai. Since 1999, school books have been printed in this script in Sikkim. In Nepal, however, its use has so far remained marginal.

19 Bairagi Kainla, referring to an article by Kajiman Khandangwa, mentions the following publications: Bajbir Thallang, Tum Yākthuñ Sāpla (1925), Bajbir Thallang \& I.S. Chemjong, Nisigek Yākthuñ Sāplā (1931); see Vairāgī Kainla [Kâĩlā], Mahāgurū Phālgunandakā Upadeśharū Tathā Satyahāñmā Panthkā Bhajanmālā (Dharan: Honorary Captain Tānhāñ Limbu and Captain Indrahān Limbu, 199o, B.s. 1947), xxxvii. Also mentioned is a book titled Yākthuì Hisāb Sāplā (no author given), apparently a textbook on numbers and calculating. 
available only locally. Nonetheless, the Yakthung Chumlung library does provide a general impression of Limbu books in circulation.

Among the library's total book holdings, very few are from the pre-199o period. These are mainly books written by Iman Singh Chemjong on Kiranti history and religion, and by followers of Phalgunanda and the Satyahangma religion. A general boost in publications can be clearly seen between ca. 1990 and 2000, in the decade following the return of multi-party democracy in Nepal. A large number of publications are from the 199os (prominent are books by Bairagi Kainla), but the number of books, especially those in the Limbu script, increases drastically after 200o. The vast majority of books in the library were published from the 2000 s up to the present. ${ }^{20}$

In terms of language, it is interesting to note that though many books are in Limbu, most of them also contain Nepali translations, and a good number are in Nepali alone. This reflects the situation of today's urban Limbu community, whose younger generation has often been raised in the Gurkha diaspora and no longer speaks Limbu. It is for this reason that many books are multilingual. Since the late 199os many have also been published in more than one script, with Devanagari alongside Limbu, and sometimes also Roman script (see below).

The books are of various genres, including not only religious topics but also novels, short stories, essays, and other secular forms of writing. Prominent are publications dealing with culture and history, to which genealogical accounts can also be added. However, publications dealing with the Mundhum are of particular importance, both in number and cultural esteem.

This is the genre that I will focus on in the following sections. After first taking a look at the early attempts to publish Mundhum texts in book form, I will then examine the important role of the followers of the Satyahangma religion in the history of Limbu book production. As mentioned above, it was this community that strongly propagated the use of the Limbu script for religious practice. Later, in the 199os, the Limbu script became ever more widely used - a development in which also academic interest played a certain role.

20 A catalog of Limbu books published in Nepal has been compiled by D.B. Angbung as part of the Austrian Science Fund (FWF) Project "Trans-Border Religion: Re-composing Limbu Rituals in the Nepal-Sikkim Borderlands" (P 29805; Principal Investigator: M. Vandenhelsken). It currently contains 324 book publications, of which only 25 are from the pre-199o period, and 58 from the 1990s. The vast majority of books, 239 , are from the 2000 up to the present ( 2 books are undated). I am grateful to the compiler for this contribution. 


\section{Early Mundhum Books: I.S. Chemjong}

The Mundhum, the body of mythological narrative and ritual practice constituting the basis of Limbu identity, was originally an oral tradition. It has only been put into writing fairly recently. The earliest specimens we know are manuscripts in the Hodgson Collection. These manuscripts (some bound as pothis $)^{21}$ are exceptional and were apparently produced for a small elite. While most deal with history and religion, they display a marked influence of Hindu ideas. Their distribution was very limited; they were apparently kept only in private collections.

Only a few books or printed volumes in the Limbu language are documented for the pre-199o period. These older publications, despite being in Limbu, tend to use Devanagari script. In Nepal, this was due in part to censorship, but there were also technical problems with printing the Kiranti script. Moreover, the use of Devanagari had the advantage of reaching a wider audience. Early examples of religious books in Kiranti script mentioned by Kainla ${ }^{22}$ as published in Darjeeling in the 1930 s are E.K. Bahadur Mereng, Tum Yakthung Samlo (1931), which appears to be on ritual songs, Buddhiraj Phago and Jasman Saba, Kirat Sam Mundhum, and Tilak Singh Nugo, Kirat Mundhum (1931). ${ }^{23}$ These publications were produced as cyclostyle copies. So far I have not had direct access to any of these books.

The most well-known, and particularly successful example of the religious genre is the book on the Kirat Mundhum by Iman Singh Chemjong, today considered a classic. ${ }^{24}$ Its subtitle inside the book is "Veda of the Kirat," but on the outside cover of the first edition (1961) this is given as the main title (Figure 1). The book includes origin myths in the Limbu language (in Devanagari script) along with a Nepali translation. Obviously, it is addressed to a wider audience.

In the preface, the author claims that this is the first translation of the Mundhum:

It would be suitable to print the Kirat Mundhum in the Kirat script, but as there is no "type" (țātp) for the Kirat script, I decided to print it in the Devanagari script. Another reason is that by printing it in Devanagari and adding a translation in the Nepali language, not only the Kirati people

\footnotetext{
21 The Nepali term pothī is used to refer to books in landscape format.

22 Kainla, Mahāgurū Phālgunandakā upadeśharū, xxxviii.

23 Subba (The Culture and Religion of the Limbu, 33) has a similar list which includes Kalusing, Yakthung Sewa Samlo (1930).

24 Chemjong, Iman Singh, Kirāt Mundhum (Kirāt ko ved) (Champaran: Rajendra Ram, 1961).
} 


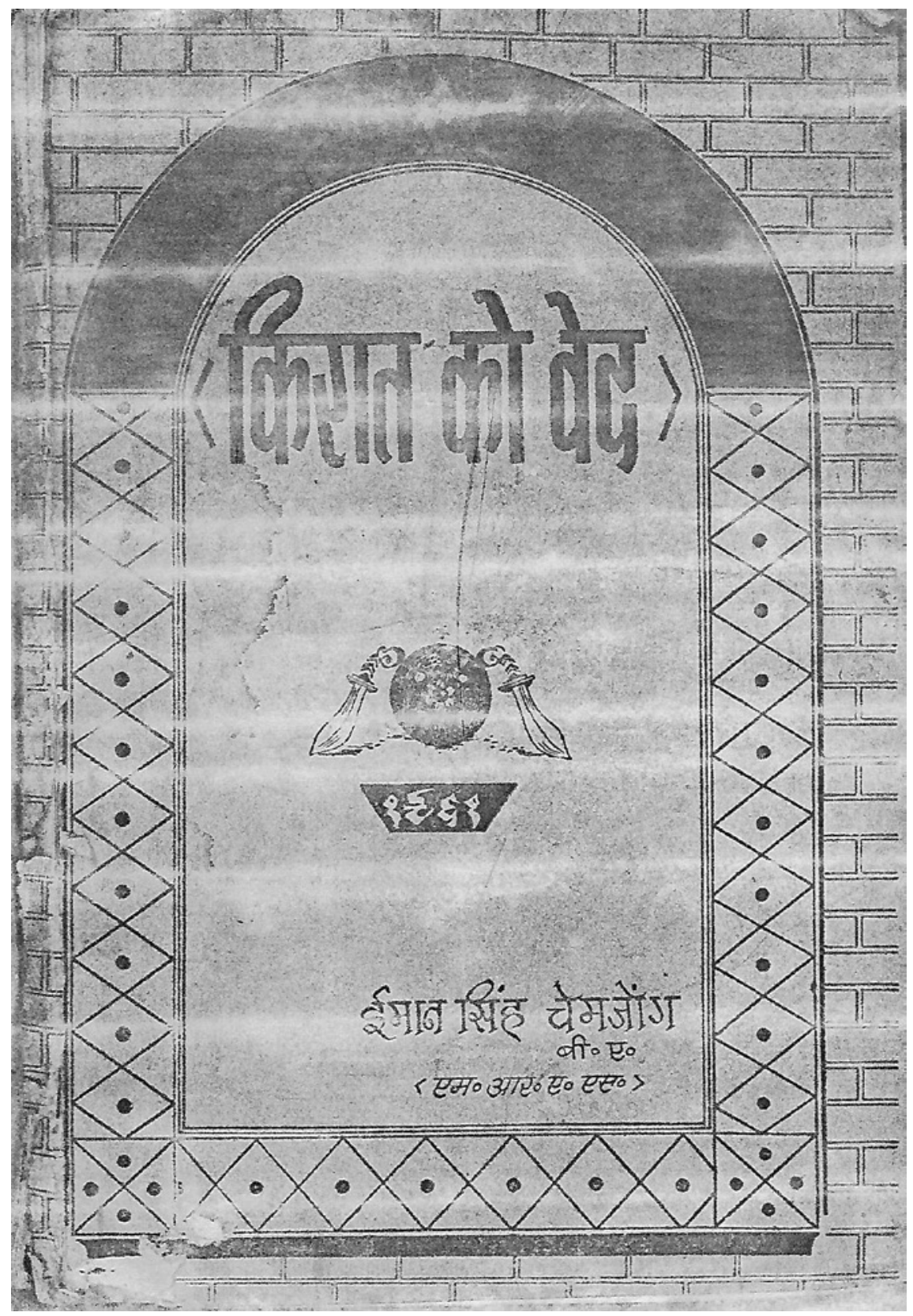

FIGURE 1 Cover of the original publication of Chemjong, 1961 
but also all those understanding the Nepali language will be able to understand matters of the Kirat Mundhum. (...) This is the first attempt to translate and print the Mundhum of the Kirat people (Kirāt jāti) into the Nepali language. ${ }^{25}$

The book is a collection of texts taken and adapted, as Chemjong writes in the preface, from an old handwritten rolled manuscript (beruva pustak) "25 hands in length" - that he found in Darjeeling in the 1920s. Bairagi Kainla ${ }^{26}$ assumes that the manuscript was given to Chemjong by an ascetic of the Josmani order. Chemjong probably finalized the transliteration and translation of the manuscript in London around 1960, when he was there working on the Hodgson Collection, but the manuscript itself is not found in that collection.

The first part of the book deals with the creation of the universe, the origin of the first human beings, the first brother-sister incest, and the origin of envy and anger. It then turns to an account of the beginnings of ritual practices, marriage, purification rites, household ceremonies, and so on. While this sequence follows a common pattern, Chemjong unfortunately does not explain the basis of his selection and so the result is a somewhat incoherent concoction of various ritual genres.

This book is still very popular among the Kiranti, not only because it is the first Nepali book on the Mundhum, but also because it has long been the only one accessible. It has gone through several editions and was recently republished in the Limbu script, in Nepali, and-for the first time-in an English translation. ${ }^{27}$ However, it should be added that today the text collection and especially its translation are often criticized as being affected by Christian ideas.

Interestingly, this volume was not first published in Nepal but in India. There is a story about this, according to which an Indian (Rajendra Ram?) once visited Chemjong in Kathmandu and apparently realized that this text was of wide-ranging importance. He borrowed (some say, stole) the already finished manuscript and secretly had it published in Bihar, thus depriving Chemjong of the benefits of his work. I have been unable to confirm this independently, but it would explain the somewhat unusual place of publication, since most other books by Chemjong were published either in Darjeeling or (after 1960) in Nepal.

25 Chemjong, Kirāt Mundhum, i (my translation).

26 Personal communication.

27 Iman Singh Chemjong, Kirat Mundhum (Veda of the Kirats). (4th ed. no place: Yalambar Foundation, Nepal \& Tummyahang Publication Fund, UK, 2015). 
A few years later Chemjong published a smaller volume in eastern Nepal of "teachings" from the Mundhum, titled Kirāt Mundhum Khāhun $(S \hat{S} i k s ̣ \bar{a}){ }^{28}$ Again, this is a collection of ritual texts, invocations, and prayers, printed in Devanagari script and followed by a translation in Nepali. The style might be called "sectional." 29

Apart from these Mundhum translations, Chemjong published most of his numerous books in Nepali. He also tried to address an international audience by publishing English translations of some of his books. One well-known example is History and Culture of the Kirat People..$^{30}$ This book is dedicated to the memory of his father, Megbar Singh Chemjong (born in 186o in Tumbung village in Panchthar District, eastern Nepal), who, as the author states in the dedication, "encouraged me to learn Kirat Script in 1916"31 (see also the short biographical sketch by K.K. Limbu). ${ }^{32}$

Though Chemjong himself was not able to publish much in Kiranti script (apart from Limbu primers), he can be seen as the unrivaled pioneer of transliteration and translation in matters of the Mundhum and the Limbu language in general. His wish may have been otherwise, but Chemjong contributed more than anyone else to making the Mundhum known in Nepali.

Chemjong's publications inspired many other Limbus to follow his style. One example of a relatively early (though strictly speaking, from the 199os) Mundhum text printed in Devanagari is Sāvālä Sāmlo Sāvalä Kuve Mundhum (Sriș̣̦i Gìtimālā Srișțiko Kathā), published by Tej Bahadur Limbu Menyangbo. ${ }^{33}$ This book contains poetic verses of the Mundhum, including the creation narrative sung by Samba priests (Limbu shamans). As in Chemjong's Mundhum edition, here the left-hand column gives the original Limbu text, the right-hand column the Nepali translation, both printed in Devanagari.

28 Iman Singh Chemjong, Kirāt Mundhum Khāhun (Śikșā). (Limbuvan: Khang Angbuhang, 1965, v.s. 2022).

29 As mentioned in Martin Gaenszle, "Introduction-Ritual Speech in the Himalayas: Oral Texts and Their Contexts," in Ritual Speech in the Himalayas: Oral Texts and Their Contexts, ed. Martin Gaenszle (Cambridge, MA: Harvard University Press, 2018), 9.

30 Iman Singh Chemjong, History and Culture of the Kirat People, 2 vols. (Phidim: Tumeng Hang, 1966). An earlier and much shorter book on Kirat history was published in Darjeeling (India): Iman Singh Chemjong, Kirāt Itihās (Darjeeling: Akhila Bharatiya Kirati [Yakthum] Chumlung Songchumbho Sabha, 1948). It appeared in a $5^{\text {th }}$ edition in 2003, published by Yakthung Chumlung, Lalitpur, Nepal.

31 Chemjong, History and Culture of the Kirat People, vol. 1.

32 Keśar Kumār Limbu, Imān Sin Cemjon Ko Jìvanī (Darjeeling: Brhat Sahitya Samsthan, 1978).

33 Tej Bahadur Limbu Menyangbo, Sāvālā Sāmlo Sāvalā Kuve Mundhum (Sriș̣i Gütimālā Srișțiko Kathā) (Taplejung, Nepal: published by the author, 1991). 


\section{Satyahangma Mundhum: Ritual Handbooks}

Books in the Limbu script were produced in particular by followers of Phalgunanda and the Satyahangma religion. Initially, they only produced manuscripts, since during the Rana period censorship was severe-especially the ban of publishing in minority scripts. Although the Mahaguru Phalgunanda was a propagator of the script, he himself did not compose any written works. Two of his main disciples took up the task of writing down the guru's recitations and words, "Sano Guru" Badrinanda Tumbapo (1907-1970) and Ranadhoj Nembang (1918-1961). They left to their successors a substantial number of handwritten texts, which in the beginning were copied as manuscripts by disciples, but later were published as printed texts and books. In particular, Ranadhoj Nembang is credited with being the person who put together the texts used for daily and life-cycle rituals. In 1958, he also produced the first wooden block print letters for publishing books in the Limbu script. ${ }^{34}$

The main publisher of these books has been Atmananda Lingden (b. 1954), who is based in Larumba, Mangsebung (Ilam District), where he resides with his large and increasing number of followers. Born in Ibhang (Ilam District) as Shyam Bahadur Lingden, he is a patrilineal great-grandson of Phalgunanda's elder brother and thus of the same Limbu clan. It is said that he was chosen by Badrinanda Tumbapo as his successor at an early age and prepared for his role already in his childhood. ${ }^{35}$ After the death of Badrinanda Tumbapo in 1970, Atmananda began to gather his own followers.

Texts based on Phalgunanda's speeches and recitations were written down by various disciples and later frequently copied. Accordingly, there are several lines of transmission. Such non-standardized manuscripts can still be seen on certain occasions, such as public recitations during anniversary events on Kartik 25, Phalgunanda's birthday. The photograph below (Figure 2) was taken at such a ritual celebration in Phidim, the capital of Panchthar District (10 Nov. 2018), when a large group of Satyahangma priests (sewa saba) performed a fire sacrifice at a hill shrine known as Sumhatlung, located above Phidim bazar.

Since about the 1980s, many of these texts have been published through the initiative and support of Atmananda. Small and handy editions have appeared in several separate volumes, such as the following:

34 Kainla, Mahāgurū Phālgunandakā upadeśharū, xxxviii.

35 Gaenszle, The Power of Script, 67-68. 


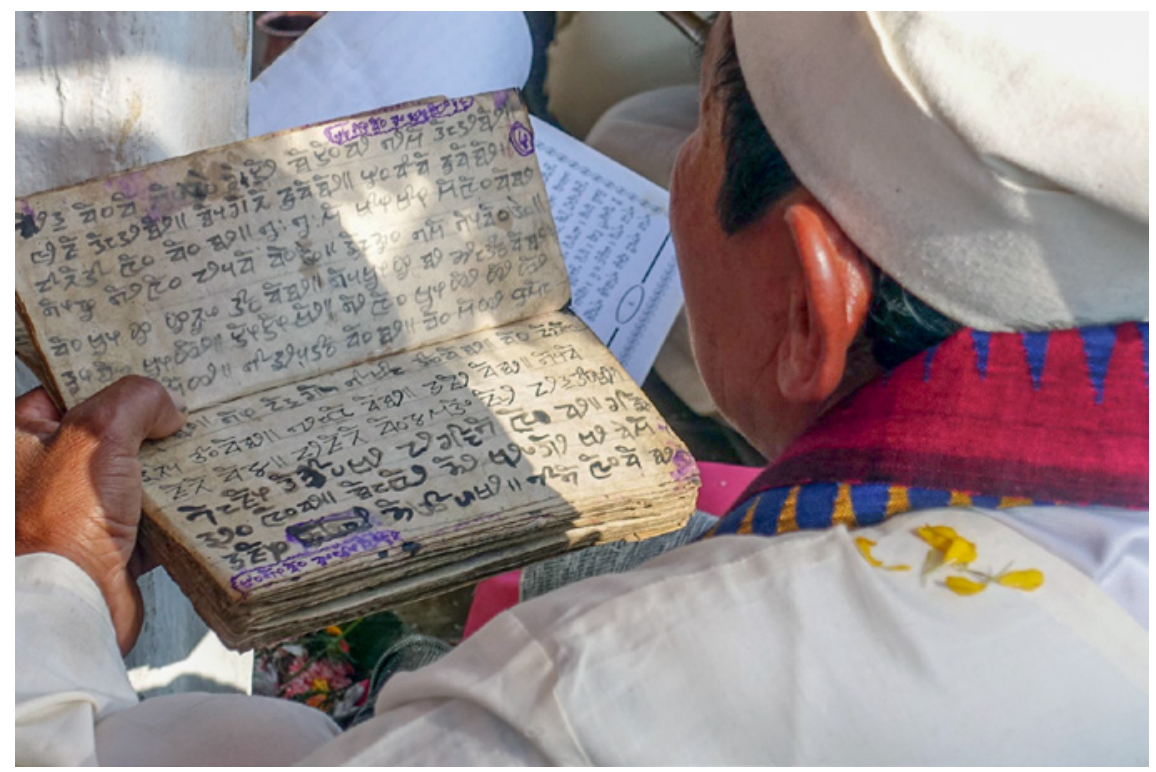

FIGURE 2 Satyahangma priest reading the Samjik Mundhum PHОTO BY MARTIN GAENSZLE 2018/HAV

Lingden, Ātmānanda. Sākmurā Wādemmā Sāmjik Mundhum [Floating away the spirit of curse], Lak (vol.) 3. Mangsebung, Ilam: Kirat Hangsam Mujotlung Manghim, 1998, v.s. 2055.

The different volumes of this publication were printed in an ordinary booklet format, like magazines, and are no longer than about a hundred pages. On the cover (Figure 3) is a sun-like drawing with the syllable ot written in the middle. This is a typical sign of the distinct tradition of Atmananda, who has replaced the usual om, also used by Phalgunanda, with his own version of the sacred sound. Many Limbus do not accept this change and see it as a kind of hubris, but followers of Atmananda use it consistently in their own recitations and prayers.

Later a comprehensive collection of Phalgunanda's recitations, to be read as religious texts, was produced in one book. These red cotton-covered bound books, in pothī format, are professionally printed in Biratnagar (Arniko Offset printers, according to the copyright page), have ISBN numbers, and are distributed from Damak (Jhapa District). They have now gone through several re-editions, still entirely in Limbu script and without any translations. Though I was told in 2013 that there are plans for translations into Nepali and other languages, these have not yet materialized. These books have now become 


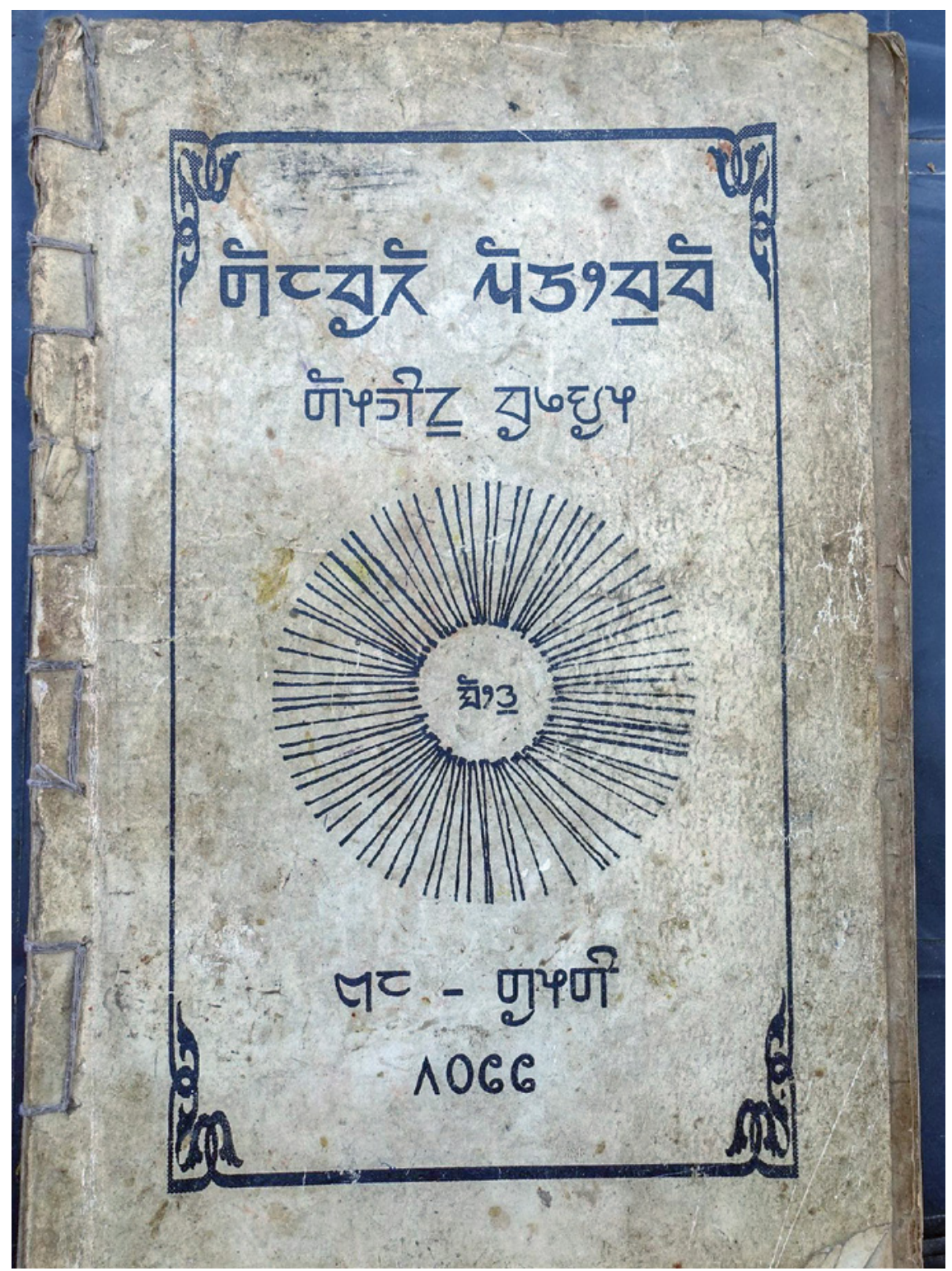

FIGURE 3 Cover of vol. 3 of the Samjik Mundhum published in 1998 PHOTO BY MARTIN GAENSZLE 2018/HAV 


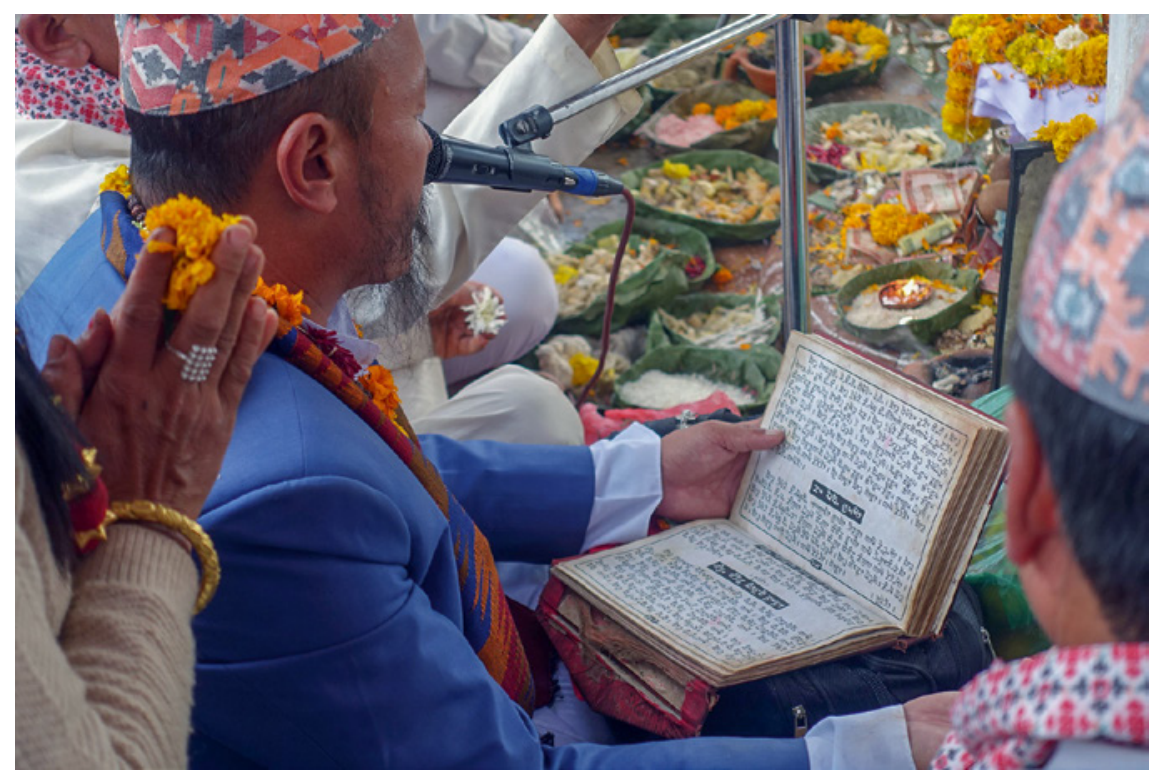

FIGURE 4 Public recitation from the Samjik Mundhum in Phidim PHOTO BY MARTIN GAENSZLE 2018/HAV

the canonical version of the major Satyahangma line following Atmananda Lingden, and it seems that most followers own a copy (Figure 4).

Lingden, Ātmānanda. Kirāt Sāmjik Mundhum, lak (vol.) 1-8. Mangsebung, Ilam: Kirat Cotlung Angsi Manggenna Sewa, 2007, v.s. 2064.

This publication contains altogether 98 Mundhum texts on 407 pages, followed by 11 drawings of altar constructions. Thus, it is clearly meant for practical use and as the basis for ritual action, not only by priests and shamans but also by laymen who have learned to recite and perform these rituals. These canonical volumes provide the necessary wording of invocations for all important occasions, such as harvest rituals (cāsok), worship of house deities (himmang), rituals for pregnant women (sāppok comen), weddings (mekkhim), funerals (e.g., sāmsāma), and many others.

In addition to the publications of this "official" successor of Phalgunanda, there is another line of the tradition that follows the original sources more critically. The editors of these volumes have made the links to the original manuscripts more transparent, publishing the texts of Phalgunanda's disciples under the title Camcik Mundhum. These books are likewise printed in 
the revised Limbu script, but they also include a Devanagari transliteration for those who cannot read the Limbu script. No translation into Nepali is offered, however.

Nemban, Nāyamhāñ Kailāsī (ed.), Camcik Mundhum.Jhapa: Sattehangma Cumbho, 1993, v.s. 205o.

This is a comprehensive collection of numbered ritual texts, on some 140 densely written pages, first given as a running text section in Limbu script, followed by the corresponding Devanagari transliteration.

In the preface to this book, the editors carefully spell out the problems and difficulties in editing these texts. They clearly state that only the handwritten manuscripts transmitted by the two main disciples, Badrinanda Tumbapo and Ranadhoj Nembang, can be considered authentic, whereas other transcripts of Phalgunanada's words are often not reliable. However, in the absence of other sources, some of the latter were also used. The exact origin of the sources of each text is provided in a table in the appendix. This quite unusual philological transparency and preciseness is lacking in most other publications.

The diligence and conscientiousness of the editors is also evident in the careful way they deal with the issue of consistent spelling. They are fully aware of the intricacies of Limbu phonology, which does not distinguish between voiced and unvoiced plosives, such as between pha and bha, or tha and dha. Only unvoiced plosives have a phonemic status, and voiced variants occur only in particular environments. The editors therefore opt to use only unvoiced variants, as for example Ningwaphu (instead of Ningwabhu) and Menthama (instead of Mendhama).

This book, it should be emphasized, was produced with non-standardized, self-made fonts using desktop publishing ("Computer Composing: Tanka Kailasi, Kathmandu"). At the time of its publication in 1993, Limbu fonts had not yet been coded under the Unicode agreement (see below).

\section{Modern Mundhum Scholarship in Nepal: From Oral Traditions to Published Texts}

The format of combining Limbu script and Devanagari transliteration was first introduced in Nepal by the writer, scholar, cultural activist and later head of the Nepal Academy Bairagi Kainla (b. 1939). In his early career he was part of an avant-garde literary movement called "Tesro Āyām" (Third Dimension), which began in Darjeeling in the 195 os and made attempts to modernize Nepali 
literature. Already at that time, Bairagi Kainla translated some Mundhum texts. ${ }^{36}$ Later, after his return to Nepal from exile in Darjeeling (1990), he became in many respects a leading figure in the literarization of Limbu. He has also done important linguistic work, as evident from his publication of Limbu grammars as well as the most comprehensive Limbu dictionary to date (Limbü-Nepālì-Añgreji Śabdakośa, Chemjong/Kainla 2010). This dictionary was originally started by Iman Singh Chemjong, and later developed into a longstanding project supported by the Nepal Academy.

One of the first scholarly books published by Bairagi Kainla in Nepal was a volume on the teachings of Phalgunanda. It not only contains ritual texts in the original Limbu with translations into Nepali, but also a lengthy introduction to the history and culture of the Satyahangma movement. It can be seen as the first academic and critical account of the tradition. Published just at the time of the first People's Movement in 199o, it was produced not in Kathmandu but in Dharan, sponsored by two ex-Gorkha soldiers with the rank of "captain." Indeed, it is important to stress that many Limbu publications are not financed by publishing houses, but by private persons who act as publisher (prakāśak) and see themselves as sponsors for a good cause.

Kāĩā, Vairāgī. Mahāgurū Phālgunandakā Upadeśharū tathā Satyahānmmā Panthkā Bhajanmālā. Dharan: Honorary Captain Tānhān Limbu and Captain Indrahān Limbu, 199o, v.s. 2047.

The text in the book itself only uses a Devanagari font, but the cover includes the title in Limbu script (Figure 5).

Bairagi Kainla's main interest lies not in the Satyahangma movement, but rather in the "authentic" Mundhum still recited in villages. More than anyone else in Nepal he has contributed to the literization or scripturalization (i.e., writing down) of the Mundhum in a multiscript and multilingual way. What is unique to his approach is that he has relied explicitly on recordings, thus documenting the living tradition of ritual performances, which he has transcribed and then edited for publication. Thus, his texts are not derived from other (hand) written versions, as in the case of Phalgunanda's followers, but from oral sources of a non-reformed tradition. In addition to these transcribed texts in Limbu script and Devanagari transliteration, he also adds Nepali translations for those readers (quite numerous among the Limbus) who do not

$36 \quad$ E.g., Khadga Bahadur Nembang, Kirāimt Mik-han Sāmlo (Kirāmìt Jāgaraṇ Gīt), trans. Bairāgī Kãĩlā (Sartap [Panchthar]: Dilli Bahadur Memvang, 1955, v.s. 2012). 


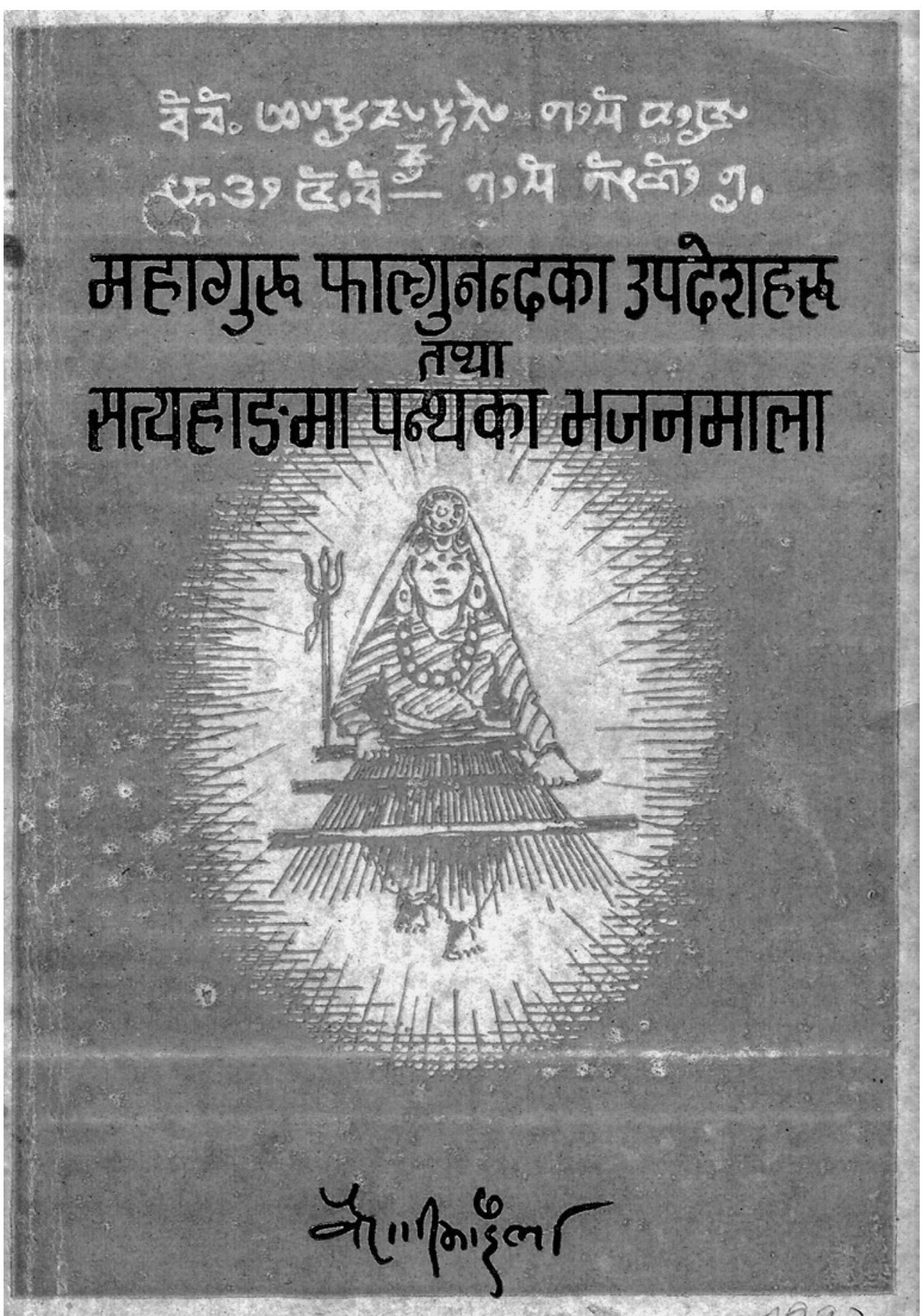

FIGURE 5 Cover of Bairagi Kainla, 1990 
understand the ritual Limbu idiom. Thus, Kainla has created a new approach to presenting Mundhum texts.

A typical example is his study on the Sāmsoghā Mundhum. ${ }^{37}$ This study contains a detailed documentation of the ritual performance used for dealing with death spirits during funeral rites. After an elaborate introduction into the cultural context of the ritual action and the necessary objects, he presents the complete ritual text in the three different forms (Limbu in Limbu script and in Devanagari, plus Nepali translation), along with some linguistic annotations.

Several other books have been published in the same form, such as Kainla's Nahen Mundhum, ${ }^{38}$ which deals with the ritual performed to get rid of jealousy and evil eye. Another example is a study on the Tangsing Takma Mundhum, ${ }^{39}$ a 389-page volume on a three-day ancestral ritual. Publishing in Limbu script along with Devanagari became increasingly popular in the 199os. Through this, competence in reading Limbu texts in Limbu script began to spread and to become more common.

This development went hand in hand with the digital transformation of print culture through the spread of desktop publishing. In 2003, the Limbu script (as it came to be called at this time) was finally standardized and released as a Unicode character set in Unicode 4.o. This step was first proposed in 1993 by Rick McGowan and others in a report to the Unicode Technical Committee. However, it was only after Boyd Michailovsky took up the initiative again with a proposal in 2000 that the plan was finally implemented. ${ }^{40}$

Through this process, different Limbu fonts became increasingly available in the first decade of the twenty-first century. What followed has been virtually an explosion of books being produced in this script, books covering a wide range of genres, including textbooks, grammars, teaching material, Limbu folk stories and songs, poems and novels, as well as history books and scholarly studies of Limbu culture and society. Encouraged by the new political climate of ethnic self-assertion, even more so after the fall in Nepal of the Hindu monarchy (in 2006), Limbu literature has begun to boom. Nonetheless, despite this emerging corpus, it should be added that an important number of these publications today are still what is sometimes referred to as "Mundhum literature," that is, religious texts, translations and commentaries.

\footnotetext{
37 Bairagi Kainla [Kāîā], Sāmsoghā Mundhum:Pretātmako ākhyān ra anușthān (Kathmandu: Limbu Sahitya ra Sanskriti Utthan tatha Prakash Samaj, 1994, v.s. 2051).

38 Bairagi Kainla [Kāîā], Nahen Mundhum: ìrșyā ra āmkhịdāhīko ākhyān (Kathmandu: Major Kesar Singh Lingden [Limbu], 1994, v.s. 2051).

39 Bairagi Kainla [Kāîlā], Tañsin Takmā Mundhum ākhyān ra anușțān, mūlpāṭh, anuvād, țippaṇi ra śabdārtha (Kathmandu: Royal Nepal Academy, 1995, v.s. 2052). Boyd Michailovsky, personal communication.
} 


\section{Conclusion}

This short sketch of the publication history of Limbu books printed in the Limbu script in Nepal clearly indicates that the interest in religious books of Mundhum texts was a driving force in the process of popularizing this alphabet. Although I.S. Chemjong had already wished to publish his Mundhum volume Kirāt ko veda in the Limbu script, he could not do so for technical reasons, since in the 1950s and early 196os glyphs for printing Limbu letters with moveable type technology were not yet available in Nepal.

Nonetheless, from the time of Phalgunanda the Limbu script became an important symbol of the reformed Limbu religion and thus was more than just an ethnic marker of distinction. In fact, it was the expression of a new ritual practice combining the ancient Kiranti oral tradition with the prestige of a modern religiosity. After the death of Phalgunanda in 1949, his disciples, above all Ranadhoj Nembang, began to create a canon of texts to preserve the tradition that had been transmitted by the Mahaguru. As Bairagi Kainla writes:

It is said that the writer or scribe of almost all ritual handbooks (karmakāndakā pustak) that we find today in the hermitages or with Satyahangma followers is Swami Ranadhoj Nembang. ${ }^{41}$

Ranadhoj Nembang printed the first Limbu book in woodblock print shortly before his death in 1961. However, the project of publishing in Limbu was stalled with the beginning of the Panchayat era and its ban on political parties (19611990). It was taken up again in the 1980s with the rise of Atmananda Lingden as the widely (if not generally) acknowledged successor of Phalgunanda and the spread of the Satyahangma movement. Hand-produced copies of religious Limbu texts began to be printed on a small scale. It was only after the fall of the Panchayat system in 1990, however, that the printing of Satyahangma books could finally be pursued and publishing became possible on large scale.

It should be stressed that the urge to publish Mundhum texts in the spirit of Chemjong (and others, also in Sikkim and Darjeeling) led to various publications by lay collectors, and thus a certain corpus of key texts already existed by the early 199os. But until that time most publications appeared in Devanagari script. It was the sectarian impetus of the Satyahangma leaders that early on pushed for the creation of a canon of texts in the Mundhum ritual language, written in Limbu script, and edited in a distinct linguistic style. This

Kainla, Mahāgurū Phālgunandakā upadeśharū, xxxviii (my translation). 
was a forceful process of both literization, turning the highly repetitive oral tradition into less redundant texts, neatly organized in chapters to be used for standard recitations. This process also implied literarization, the creation of a canonized literature, although the emerging corpus was not acknowledged by all Limbu. Nonetheless, the mere existence of such books contributed to ethnic pride and inspired the production of similar Mundhum books, leading to a growing "script community" sharing a common "semiotic ideology." 42 This community of readers and reciters was far from homogenous. As has been shown, competing traditions within the Satyahangma religion developed, and there are also regional differences. But the Limbu who used their unique script were nevertheless united through its difference, thus making themselves distinct from other communities. ${ }^{43}$

The situation became more complex and diverse when Nepal opened up to ethnic demands, and the previously heavily censured publication market was transformed into a busy and lively public sphere. An important influence has been the literary figure and ethnic scholar-activist Bairagi Kainla. Whereas Satyahangma followers emphasized the standardization and canonization of a textual corpus, regarding this as the "true" tradition, Bairagi Kainla took a different direction by closely following and documenting the oral tradition, thus adopting a more scholarly approach. In fact, he told me that his presentation of Limbu texts was partly inspired by András Höfer's "ethno-philological" publications of Tamang ritual texts. ${ }^{44}$ Rather than following in the footsteps of Phalgunanda and his followers, Bairagi Kainla has continued the project started by I.S. Chemjong, namely the academic study of Limbu language and culture. Not surprisingly, it was above all Kainla, through the Nepal Academy, who pursued the Limbu-Nepali-English dictionary project started by Chemjong, and who popularized the use of bilingual and bi-scripted editions.

42 This concept refers to the indigenous valuation of signs, to "people's underlying assumptions about what signs are." Webb Keane, "On Semiotic Ideology," Signs and Society 6, no. 1 (2018): 64-87. For the Limbu, possessing their own script, an "ancient" but lost and "rediscovered" sign system, changed the tradition in fundamental ways. Clearly the transformation of the Mundhum's sacred words into printed books in an ethnic script has brought about a different view and experience of these texts. See also the special issue on "Sign and Script in South Asia: Media and Semiotic Mediation," Signs and Society 8, no. 1 (2002).

43 A fine example of such competing communities with their distinct "tribal scripts" is the weekly publication of the Sikkimese government Sikkim Herald, which appears in no less than 11 different scripts; Shneiderman \& Turin, "Seeking the Tribe," 54-58.

44 Such as András Höfer, Tamang Ritual Texts I. Preliminary Studies in the Folk Religion of an Ethnic Minority in Nepal (Wiesbaden: Franz Steiner Verlag, 1981). 
Both of these developments, one religious and the other academic, were given a boost through technological developments. There was a tremendous impact on the publication business when the Limbu writing system received a final standardization by B.B. Subba in the 196os, and again, and in particular, when standard Unicode fonts for Limbu (based on the standardized writing system) for computer typesetting were introduced in 2003. The subsequent boom in publishing in the Limbu script, in single-script as well as multi-script publications (sometimes including Roman script), has caused the transformation of a religious culture, a culture that until the 199os was largely seen-mainly by outsiders - as a part of Hinduism. It has now developed a distinct identity of its own. Religious books, one could argue, were the standard model of Limbu literature, and the use of the Limbu script, closely linked to the Mundhum tradition, became a must in order to be truly Limbu. Thus, the sacredness of ritual writing, or grapholatry, was an important force in this process of literarization (creation of literature). While the sanctity of these religious letters has been diluted in this process for ordinary, more profane literature, over the course of time, its original sacredness is bound to be diminished by the pervasive spread of the printed word.

\section{Acknowledgements}

Much of the research on which this article is based was carried out in the context of the Austrian Science Fund (FWF) Project "Trans-Border Religion: Re-composing Limbu rituals in the Nepal-Sikkim borderlands" (P 29805; Nov. 2016-Oct. 2020, Principal Investigator: Mélanie Vandenhelsken, project website: limbu-rituals.univie.ac.at). I am grateful to the funding agency and the project team for making this study possible. For valuable comments and suggestions, I thank Alaka Chudal, Bairagi Kainla, Boyd Michailovsky, Cristina Pecchia, Novel Kishor Rai, Vishnu Singh Rai, and the anonymous reviewers. I further thank Cynthia Peck-Kubaczek and the PHEN team for their editorial input. And I thank Mélanie Vandenhelsken for having given me access to the photographs of two books that she took in the Kirat Yakthung Chumlung office, Lalitpur: Limbu Menyangbo, Sāvālā Sāmlo Sāvalā Kuve Mundhum, and Nembang, Camcik Mundhum. These images and other materials resulting from the project are currently archived at the Himalaya Archive Vienna (hav.univie. ac.at), Limbu Collection. 


\section{References}

Anderson, Benedict. Imagined Communities: Reflections on the Origins and Spread of Nationalism [1983]. London: Verso, 1991.

свs (Central Bureau of Statistics). National Population and Housing Census 2011. Kathmandu: Government of Nepal (National Planning Commission Secretariat), 2012.

Chemjong, Iman Singh. Kirāt Itihās. Darjeeling: Akhila Bharatiya Kirati (Yakthum) Chumlung Songchumbho Sabha, 1948.

Chemjong, Iman Singh. Kirāt Mundhum (Kirāt ko ved). Champaran: Rājendra Rām, 1961.

Chemjong, Iman Singh. Kirāt Mundhum Khāhun (Śikșā). Limbuvān: Khañg Āngbuhāng, 1965 , v.s. 2022.

Chemjong, Iman Singh. History and Culture of the Kirat People. 2 vols. Phidim: Tumeng Hang, 1966.

Chemjong, Iman Singh and Bairagi Kainla. Limbū-Nepālī-Añgrejü Śabdakośa. Īmānasiṃha Cemjoṅkṛta Limbū-Nepālī-Aṅgrejī śabdakośako parivarddhita ra parimārjita samskaraṇa = Limbu-Nepali-English dictionary (Third edition). Kathmandu: Nepal Academy (Nepāla Prajñā-Pratișțhān), 2010 (1st ed. 1961).

Chemjong, Iman Singh. Kirat Mundhum (Veda of the Kirats). No place: Yalambar Foundation, Nepal \& Tummyahang Publication Fund, UK, 2015.

Choksi, Nishaant. "From Language to Script: Graphic Practice and the Politics of Authority in Santali-Language Print Media, Eastern India." Modern Asian Studies 51, no. 5 (2017): 1519-156o.

Dhungel, Ramesh. "The Long-ago Fight for Kirant Identity." Himal Southasian (2006, October): $5^{2-56 .}$

Driem, George van. A Grammar of Limbu. Berlin, etc.: Mouton de Gruyter, 1987.

Ekvall, Robert. Religious Observances in Tibet: Patterns and Function. Chicago: Chicago University Press, 1964.

Gaenszle, Martin. Ancestral Voices: Oral Ritual Texts and their Social Contexts among the Mewahang Rai in East Nepal. Münster, Hamburg, London: LIT Verlag, 2002.

Gaenszle, Martin. "Scripturalisation of Ritual in Eastern Nepal." In Ritual, Heritage and Identity: The Politics of Culture and Performance in a Globalised World, edited by Christiane Brosius and Karin M. Polit, 281-297. New Delhi: Routledge, 2011.

Gaenszle, Martin. “The Power of Script: Phalgunanda's Role in the Formation of Kiranti Ethnicity." In Routeing Democracy in the Himalayas: Experiments and Experiences, edited by Vibha Arora, N. Jayaram, 50-73. New Delhi: Routledge, 2013.

Gaenszle, Martin. "Redefining Kiranti Religion in Contemporary Nepal." In Religion, Secularism, and Ethnicity in Contemporary Nepal, edited by David N. Gellner, Sondra S. Hausner and Chiara Letizia, 326-352. New Delhi: Oxford University Press, 2016. 
Gaenszle, Martin, ed. Ritual Speech in the Himalayas: Oral Texts and their Contexts. Harvard Oriental Series 93. Cambridge, MA: Harvard University Press, 2018.

Höfer, András. Tamang Ritual Texts I. Preliminary Studies in the Folk Religion of an Ethnic Minority in Nepal. Wiesbaden: Franz Steiner Verlag, 1981.

Kainla [Kāĩlā], Vairāgī. Mahāgurū Phālgunandakā Upadeśharū tathā Satyahāñmā Panthkā Bhajanmālā. Dharan: Honorary Captain Tānhhān Limbu and Captain Indrahān Limbu, 1990 (v.s. 2047).

Kainla [Kāĩlā], Vairāgī. Sāmsoghā Mundhum: Pretātmako Ākhyān ra Anușțhān. Kathmandu: Limbu Sahitya ra Sanskriti Utthan tatha Prakash Samaj, 1994 (v.s. 2051).

Kainla [Kāĩlā], Vairāgī. Nahen Mundhum: İrșyā ra Āmkhīẹāhīko Ākhyān. Kathmandu: Major Kesar Singh Lingden (Limbu), 1994 (v.s. 2051).

Kainla [Kāĩlā], Vairāgī. Tan்sin Takmā Mundhum Ākhyān ra Anușthān, Mūlpāṭh, Anuvād, Tippañi ra Śabdārtha. Kathmandu: Royal Nepal Academy, 1995 (v.s. 2052).

Keane, Webb. "On Semiotic Ideology." Signs and Society 6, no. 1 (2018): 64-87.

Limbu, Kesar Kumar. Imān Sin Cemjoǹ ko Jìvanī. Darjeeling: Brhat Sahitya Samsthan, 1978.

Limbu Menyangbo, Tej Bahādur. Sāvālā Sāmlo Sāvalā Kuve Mundhum (Srișți Gūtimālā Sriștiko Kathā). Taplejung, Limbuwan: published by the author, 1991.

Lingden, Atmananda. Sākmurā Wādemmā Sāmjik Mundhum [Floating away the spirit of curse], Lak (vol.) 3. Mangsebung, Ilam: Kirat Hangsam Mujotlung Manghim, 1998 (v.s. 2055).

Lingden, Atmananda. Kirāt Sāmjik Mundhum, lak (vol.) 1-8. Mangsebung, Ilam: Kirat Cotlung Angsi Manggenna Sewa, 2007 (v.s. 2064).

Nembang, Khadga Bahadur. Kirāmit Mik-han Sāmlo (Kirāimt Jāgaraṇ Gït). Translated by Bairāgī Kāĩlā. Sartap (Panchthar): Dilli Bahadur Memvang, 1955 (v.s. 2012).

Nembang, Nayamhang Kailasi, ed. Camcik Mundhum. Jhapa: Sattehangma Cumbho, 1993, (V.S. 2050).

Orsini, Francesca, ed. The History of the Book in South Asia. Farnham \& Burlington: Ashgate, 2013.

Pollock, Sheldon. "India in the Vernacular Millennium: Literary Culture and Polity, 1000-1500." Daedalus 127, no. 3 (1998): 41-74.

Pollock, Sheldon. The Language of the Gods in the World of Men: Sanskrit, Culture, and Power in Premodern India. Berkeley: University of California Press, 2006.

Shneiderman, Sara. Rituals of Ethnicity: Thangmi Identities between Nepal and India. Philadelphia: University of Pennsylvania Press, 2015.

Shneiderman, Sara and Mark Turin. "Seeking the Tribe: Ethno-Politics in Darjeeling and Sikkim." Himal Southasian 19, no. 2 (2006): 54-58. 
Sprigg, R.K. "Limbu Books in the Kiranti Script." In Akten des vierundzwanzigsten internationalen Orientalisten-Kongresses, München, 1957, edited by Herbert Franke, 590592. Wiesbaden: Steiner Verlag, 1959.

Subba, Chaitanya. The Culture and Religion of Limbus. Kathmandu: K.B. Subba, 1995.

Udupa, Sahana. "Print Communalism: The Press and the Non-Brahmin Movement in Early Mysore, 190o-3o." Contributions to Indian Sociology 44, no. 3 (2010): 265-297. Vandenhelsken, Mélanie and Martin Gaenszle. "Limbu Religion and the Remaking of Community." In Brill's Encyclopedia of Religions of Indigenous People of South Asia, edited by Marine Carrin, Gérard Toffin. Leiden: Brill, 2019. Accessed April 17, 2021, http://dx.doi.org/10.1163/2665-9093_BERO_COM_O32248.

Whelpton, John and Michael Hutt. "The Catalogue of the Hodgson Collection in the British Library." European Bulletin of Himalayan Research 39 (2011): 128-143. 